\title{
Characterization of Extracellular Dextranase from a Novel Halophilic Bacillus subtilis NRC-B233b a Mutagenic Honey Isolate under Solid State Fermentation
}

\author{
MONA A. ESAWY**1, SARA H. MANSOUR ${ }^{1}$, EMAN F. AHMED ${ }^{1}$, NAZIHA M. \\ HASSANEIN ${ }^{2}$, HESHAM A. EL ENSHASY ${ }^{3}$ \\ ${ }^{1}$ Department of Chemistry of Microbial and Natural Products, National Research Centre \\ (NRC); Dokki, Cairo, Egypt \\ ${ }^{2}$ Department of microbiology, Faculty of Science, Ain Shams Univ., Cairo, Egypt \\ ${ }^{3}$ Institute of Bioproducts Development, Universiti Teknologi Malaysia (UTM), Skudai, \\ Johor, Malaysia. \\ mona_esawy@hotmail.com
}

Received 02 November 2011; Accepted 07 January 2012

\begin{abstract}
Bacillus subtilis NRC-B233b was isolated from Libyan honey sample proved to be a potent dextranase producer by applying solid state fermentation and utilizing corn flour as the sole carbon source. The optimized culture conditions for dextranase productions were $37^{\circ} \mathrm{C}, \mathrm{pH} 10,32 \mathrm{~h}$, and $20 \%(\mathrm{v} / \mathrm{w})$ moisture content. A unique character of this isolate is its ability to produce steady dextranase irrespective to the presence of $\mathrm{NaCl}$ in the medium. The addition of $0.175 \mathrm{Mm} \mathrm{CrCl}_{3}$ increased the enzyme production by about 4.5 fold. Further improvement in enzyme production was achieved by simple UV mutation which increased the enzyme production up to about $2842 \mathrm{U} / \mathrm{g}$. The crude extract has been partially purified about 112 -fold from crude extract by only two purification steps involving ultra-filtration. The partially purified dextranase showed its maximum activity at $\mathrm{pH} 9.2$ and $70^{\circ} \mathrm{C}$. It retained full activity $(100 \%)$ at $75^{\circ} \mathrm{C}$ for one hour. Dextranase activity increased about 4 fold in the presence of $10 \% \mathrm{NaCl}$. This enzyme showed variable degradation effect on different types of dextran and its derivatives. The treatment of viscous sugar cane juice with the enzyme preparation resulted in clear visual dextran hydrolysis. These results suggest that the dextranase produced by Bacillus subtilis NRC-B233b is industrially applicable.
\end{abstract}

Keywords: halophilic dextranase, thermophilic dextranase, Bacillus subtilis, dextranase stability.

\section{Introduction}

Honey can be considered as a reservoir for microbes that withstand the concentrated sugar, acidity. These microbes also contribute to the antimicrobial characters of honey. The 
osmophilic feature of the honey could hypothesize the presence of moderate halophilic bacteria with new properties.

Recently, a considerable attention has been given to the enzymes produced by moderately halophilic microorganisms and their biotechnological potentials [1, 2]. Enzymes with optimal activity at high-salt concentrations are useful for many harsh industrial processes, where concentrated salt solutions otherwise inhibits many enzymatic conversions [3-5]. Halophilic enzymes perform the same enzyme function as their non halophilic counterparts, but they have substantially different properties. Among these, requirement for high-salt concentrations in 1-4 Molar range for activity and stability. In spite of the fact that many moderately and extremely halophilic microorganisms have been well described, the apparent thermostable properties of their enzymes, especially from moderately halophilic bacteria, have not studied extensively [6].

Dextran is a collective name for high-molecular-weight polymers composed of D-glucose units connected with $\alpha-1,6$ linkages and various amounts of side branches linked with $\alpha-1,2$, $\alpha-1,3$, or $\alpha-1,4$ to the main chains [7]. Dextranase (EC 3.2.1.11; $\alpha$-1,6-glucan-6glucanohydrolase) hydrolyzes the 1-6 glycosidic linkage in dextran chain [7]. The enzyme cleaves the linkages of the dextran molecule and releases shorter isomaltosaccharides. This enzyme was found in a variety of bacteria belong to Bacillus species such as: $B$. subtilis and $B$. megaterium [8]. In sugar-processing industries, contamination by dextran causes an extensive problem by increasing the viscosity of the sugar juice. The use of dextranase in sugar production process can reduces the viscosity significantly [9]. For many industrial applications, it is necessary to use a dextranase which is stable and has neutral to alkaline $\mathrm{pH}$ range. A large number of industrial processes in the areas of environmental industry and food biotechnology utilize enzymes at some stage or the other throughout the production process.

Of different processes for enzyme production, solid state fermentation (SSF) holds tremendous potential for the production of enzymes. It can be of special interest in those processes where the crude fermented products may be used directly as enzyme sources. Among the several factors that are important for microbial growth and enzyme production using a particular substrate, particle size and moisture level/water activity are the most critical [10-12].

The aim of the present study is to examine the production of dextranase from honey isolate under SSF and to optimize the fermentation medium for maximum enzyme production. Mutation of the producer bacterium was one of our purposes to improve the production of the enzyme. Furthermore, partial purification, and characterization of dextranase were investigated.

\section{Experimental}

\section{Isolation of Bacterial Strain from Honey}

One hundred micro liters of honey (kashmiry honey: a honey bee collecting nectar from desert flower, Saudi Arabia) was spread on solid agar plates composed of (g/l): dextran, 10; $\mathrm{MgSO}_{4}, 0.02 ; \mathrm{K}_{2} \mathrm{HPO}_{4}, 5.5$. After drying for $20 \mathrm{~min}$ in a laminar flow hood, the plates were incubated at $50{ }^{\circ} \mathrm{C}$ for $24 \mathrm{~h}$. Among different strains isolated, the highest dextranase producer was further purified and characterized. The purity of the isolate was assessed by colony morphology and direct microscopic observation.

\section{Identification of the Isolate}

The isolated strains were examined by microscopic observation, and the selected culture was purified and tested for Gram's staining. Growth at different temperatures $(25,30,40,50$, and 
$\left.60^{\circ} \mathrm{C}\right), \mathrm{NaCl}$ concentrations $(0,4,8,12$, and $15 \%)$ and $\mathrm{pH}(4-11)$ were tested in nutrient broth. Identification was based on morphological, 16S rRNA sequence and biochemical tests (API). The 16srDNA was amplified by polymerase chain reaction (PCR) using primers designed to amplify $1500 \mathrm{bp}$ fragment of the 16srDNA region. The forward primer was 5'AGAGTTTGATCMTGGCTCAG3' and the reverse primer was 5'TACGGYTACCTTGTTACGACTT3'. After full identification, the bacterium was deposited in NRC culture collection under the name Bacillus subtilis NRC-B233b [13-15]. Biochemical test (API) was achieved in the Holding Company for Biological Products and Vaccines (VACCERA), Cairo, Egypt.

\section{Cell Banking}

This strain was sub cultured in agar medium and the arisen colonies were harvested by glycerol solution (20\%) and put in series of $2 \mathrm{ml}$. crygen vials (Nalgene, USA). The tubes were frozen immediately at $-20{ }^{\circ} \mathrm{C}$ for $24 \mathrm{~h}$ followed by storage as working cell bank at -80 ${ }^{\circ} \mathrm{C}$ for further use. This was an important step to ensure that the starter culture of each experiments of the same generation number.

\section{Dextranase production media}

The medium used for dextranase production had the following composition (g/l): dextran, 10 ; yeast extract, $2.5 ; \mathrm{MgSO}_{4}, 0.02 ; \mathrm{K}_{2} \mathrm{HPO}_{4}, 5.5$ (separately autoclaved).

\section{Cellular Production}

Cultivation was carried out in 250-ml Erlenmeyer flasks. Each flask contained $50 \mathrm{ml}$ of production medium and was sterilized for 15 minutes at $121^{\circ} \mathrm{C}$. The flasks were then inoculated with $2.0 \mathrm{ml}$ spore suspention and incubated in a static incubator for 24 hours at $30{ }^{\circ} \mathrm{C}$. The culture broth was then centrifuged in a refrigerated centrifuge (K70; Janektzki, Germany) at $10,397 \mathrm{~g}$ to separate the bacterial cells from the culture medium. Each fermentation run was performed in triplicate, and analyses were carried out in duplicate. The data given are the means of all the measurements. The mean standard error of the dextranase estimate was $\mathrm{f} 0-25 \mathrm{U}$ and ranged from $\mathrm{f} 0.002$ to $\mathrm{f} \pm 3.997$

\section{Solid state Experiment}

Ten grams of each substrate in 250 Erlenmeyer flasks (corn flour-, wheat flour- , commercial starch-, wheat bran or ground rice) were mixed with $8 \mathrm{ml}$ of the production medium and autoclaved at $121{ }^{\circ} \mathrm{C}$ for $30 \mathrm{~min}$. Flasks were cooled at room temperature and each flask was inoculated with $2 \mathrm{ml}$ of bacterial suspension $\left(1 \mathrm{OD}_{600}\right)$. All cultivations were performed in triplicate, and analyses were carried out in duplicate (i.e. the data given are the mean of six measurements).

\section{Extraction and Enzyme Recovery}

Dextranase was extracted from the substrate using distilled water as the extracting agent [17]. Ten volumes of distilled water per gram substrate (based on initial dry weight of the substrate) was added to the fermented medium and the extraction was performed by agitation at room temperature in a rotary shaker for $60 \mathrm{~min}$ at $150 \mathrm{rpm}$. The slurry was then squeezed through Sun dried muslin cloth previously washed in distilled water and clarified by centrifugation at $5,000 \mathrm{rpm}$ at $4{ }^{\circ} \mathrm{C}$ for $15 \mathrm{~min}$. The clear supernatant was used to assay for the enzyme activity and protein content.

\section{Optimization of Culture Conditions}

All the following experiments were conducted under SSF in the presence of corn flour as the best substrate. The influence of temperature on growth and production of dextranase was studied at $25{ }^{\circ} \mathrm{C}, 30{ }^{\circ} \mathrm{C}, 37{ }^{\circ} \mathrm{C}, 50{ }^{\circ} \mathrm{C}$ and $60{ }^{\circ} \mathrm{C}$. The effect of the incubation period was 
studied at $(8,24,32,48,56$ and $72 \mathrm{hrs})$, at $37^{\circ} \mathrm{C}$. Effect of moisture content was achieved using different volumes of distilled water $(50,100,150,200,250,300$ and $500 \%(\mathrm{v} / \mathrm{w})$ at 37 ${ }^{\circ} \mathrm{C}$. Dextranase production was also investigated with the initial $\mathrm{pH}$ adjusted to 3.2-11.2 at $37^{\circ} \mathrm{C}$.

\section{Nutrient Additives}

Nutrient additives included $\mathrm{NaCl}(0-15 \mathrm{~g} / \mathrm{L})$, and $0.1 \mathrm{M}\left(\mathrm{FeSO}_{4}, \mathrm{EDTA}, \mathrm{MnCl}_{2}, \mathrm{NaH}_{2} \mathrm{PO}_{4}\right.$, $, \mathrm{FeCl}_{3}, \mathrm{LiSO}_{4}, \mathrm{MgSO}_{4}, \mathrm{~K}_{2} \mathrm{Cr}_{2} \mathrm{O}_{7}, \mathrm{KI}, \mathrm{K}_{2} \mathrm{HPO}_{4}, \mathrm{Na}_{2} \mathrm{HAsO}_{4}, \mathrm{ZnSO}_{4}, \mathrm{~K}_{2} \mathrm{~S}_{2} \mathrm{O}_{8}, \mathrm{KH}_{2} \mathrm{PO}_{4}$ ${ }_{,} \mathrm{CaCl}_{2}, \mathrm{KCl}, \mathrm{AlCl}_{3}, \mathrm{CuSO}_{4}$ and $\mathrm{NaCO}_{3}$ ) with each salt added separately in the production medium. Also $(5 \mathrm{~g} / \mathrm{L})$ of the different organic nitrogen sources; urea, beef extract, yeast extract, ammonium chloride, peptone, casein, and corn steep were used.

\section{Determination of Enzyme Activity}

The activity was measured using the Somogy-Nelson method using dextran of molecular weight $250 \mathrm{KDa}$ as substrate [17]. Based on this method, $0.3 \mathrm{ml}$ of the filtrate medium was incubated with $0.7 \mathrm{ml}$ of $2.5 \%$ dextrane in $0.1 \mathrm{M}$ sodium citrate buffer at $\mathrm{pH} 5.2$ and $50^{\circ} \mathrm{C}$. After incubation for $15 \mathrm{~min}, 0.25 \mathrm{ml}$ was taken for analysis. One unit (U) of enzyme is defined as the amount of enzyme which liberates $1 \mu \mathrm{g}$ of glucose equivalent in one min.

The amount of total protein was determined by the method of Lowry et al., (1956). This methods is based on the tyrosine and tryptophan content [18].

\section{Sugar Determination by Chromatographic Method}

Hydrolytic products of dextran were analyzed by paper chromatography and by HPLC method. Paper chromatography for sugar determination was performed according to Block et al., [19]. The reaction mixtures at the end of incubation time were boiled for 3 min to stop the enzymatic reaction. The obtained mixtures were plotted on chromatographic paper (Whatman 1). Chromatographic separation was carried out using a solvent system of $n$ butanol: acetone: water $(4: 5: 1)$ and detected by spraying with aniline hydrogen phthalate. The acid hydrolysate of the hydrolytic product of dextran was analyzed using high-pressure liquid chromatography (HPLC). A $7.8 \times 300-\mathrm{mm}$ PL-HI-PLEXPB column linked to a differential refractometer was used for sugar analaysis. The column temperature was maintained at $80{ }^{\circ} \mathrm{C}$ and the aqueous mobile phase was delivered at a flow rate of 0.6 $\mathrm{ml} / \mathrm{min}$. Same method was previously done by [20]

\section{Storage Stability}

The culture filtrate of the crude dextranase enzyme was stored in distilled water at $4^{\circ} \mathrm{C}$ for 4 months. The activity was measured every 2 weeks using $3.5 \mathrm{mg}$ of protein as previously mentioned.

\section{Mutation}

Mutation of isolated bacterium Bacillus subtilis NRC-B233b from honey was performed according to the method of Abdel-aziz, et al., [21] with some modification: Twenty four hours old Bacillus subtilis NRC-B233b culture was cultivated in broth medium, and then suspended in $50 \mathrm{ml}$ saline solution. Cell suspension was transferred to $14 \mathrm{~cm}$ diameter petri dishes. All samples were placed at distance of $20 \mathrm{~cm}$ from UV Lamp (40 W). Cell suspension was irradiated for $1 \mathrm{hr}$. One $\mathrm{ml}$ of treated culture was taken at different time intervals of 2 minutes. Treated culture were kept in dark for onehour before being diluted and spreaded onto thecomplete medium (CM). Irradiated cultures were maintained on nutrient agar containing the following components $(\mathrm{g} / \mathrm{L})$ : glucose, 10 , peptone 6 , yeast extract 3 , meat extract 1.5 and agar 28 . 


\section{Repeated Batch}

The freshly prepared mutagenic Bacillus subtilis $N R C-B 233 b$ was cultivated under the optimized medium and conditions previously discussed, and then the enzyme activity was determined. Renew and cultivation for the mutagenic Bacillus subtilis NRC-B233b was repeated ten times and its dextranase activity was evaluated.

\section{Partial Purification of Dextranase}

The first step of purification was carried out by passing 2 liters of crude enzyme through a Pellicon Cassette system with a membrane PLGC Cassette 10.000 NMWL (Low protein binding). The retentate and permeate obtained were checked for dextranase activity.

Fractional precipitation using different concentrations (30-80\%) of acetone [22] was performed as follows: $100 \mathrm{ml}$ permeate fraction was precipitated using $30 \% \mathrm{v} / \mathrm{v}$ solvent and centrifuged at $2850 \mathrm{~g}$ for $10 \mathrm{~min}$ in a cooling centrifuge, (fraction 1) then $40 \% \mathrm{v} / \mathrm{v}$ solvent was used to precipitate the supernatant (fraction 2). This method was repeated to reach to $80 \% \mathrm{v} / \mathrm{v}$ solvent concentration and the fraction that contained the highest enzyme activity was chosen for further experiments.

\section{Effect of $p H$ on Partially Purified Dextranase}

Enzyme activity was studied over at different $\mathrm{pH}$ values $3.2,4.2,5,2$ and 6,2 of ( $0.1 \mathrm{M}$ ) sodium - citrate buffer, 7, 2 and 8,2 of $(0.2 \mathrm{M})$ tris - buffer, 9.2, 10.2 of ( $0.2 \mathrm{M})$ glycine $-\mathrm{NaOH}$ buffer.

\section{Influence of Incubation Temperature}

In this experiment, $0.3 \mathrm{ml}$ of partially purified enzyme was incubated with $0.7 \mathrm{ml}$ of $2.5 \%$ dextrane and incubated at different temperatures $\left(35-75^{\circ} \mathrm{C}\right)$ for $15 \mathrm{~min}$.

\section{Thermal Stability}

Profile was studied by incubating the enzyme preparation at various temperatures, (40-75 ${ }^{\circ} \mathrm{C}$ ) in glycine $\mathrm{NaOH}$ buffer $0.05 \mathrm{M}$, at $\mathrm{pH} 10$ for different incubation period (15-60 min) and the residual activity was measured at $70^{\circ} \mathrm{C}$.

The $\mathrm{pH}$ stability of dextranase enzyme was examined by incubating the enzyme at room temperature at $0.5,1,1.5$, and 2 hours and different $\mathrm{pH}$ values 5.2 and 6.2 of ( $0.1 \mathrm{M})$ sodium - citrate buffer, 7.2 and 8.2 of $(0.2 \mathrm{M})$ tris - buffer and 9.2 and 10.2 of ( $0.2 \mathrm{M}$ ) glycine $-\mathrm{NaOH}$ buffer. The residual activity was measured as mentioned previously.

\section{Influence of Salts on Enzyme Activity}

One $\mathrm{ml}$ of partially purified enzyme was dissolved in $1 \mathrm{ml}$ of $0.1 \mathrm{M}$ of the following salts: $\mathrm{MnCl}_{2}, \mathrm{CrCl}_{3}$, EDTA, $\mathrm{CaCl}_{2}, \mathrm{MgSO}_{4} \cdot 7 \mathrm{H}_{2} \mathrm{O}, \mathrm{CuSO}_{4} \cdot 5 \mathrm{H}_{2} \mathrm{O}, \mathrm{AlCl}_{3} \cdot 6 \mathrm{H}_{2} \mathrm{O}, \mathrm{CaCO}_{3}, \mathrm{KCl}$ and $\mathrm{ZnSO}_{4} .7 \mathrm{H}_{2} \mathrm{O}$ ) then incubated with the substrate and the activity was measured.

\section{Effect of Different Concentrations of $\mathrm{NaCl}$}

One $\mathrm{ml}$ of partially purified enzyme was dissolved in $1 \mathrm{ml}$ of different concentrations (1$15 \%) \mathrm{NaCl}$ and incubated at room temperature for one hour and the enzyme activity was determined as described previously.

\section{Effect of Enzyme on Different Molecular Weights of Dextrans}

Partially purified enzyme was used to degrade dextrans of different molecular weights (250 000, and 275000), blue dextran (2000) and sephadex G-100 (1000-10000), also some carbohydrates such as starch, amylopectin, maltose and inulin were used (Table 5). 


\section{Effect of Partial Pure Dextranase on Sugarcane Juice}

Different concentrations of partial purified enzymes (237, 475, 712, 950 and $1185 \mathrm{U})$ were added to stored sugar cane juice of high viscosity $(10 \mathrm{ml})$ and incubated at $70^{\circ} \mathrm{C}$ for 2 hours and the change in sugar juice viscosity was determined by a U-shapped glass Oswald viscometer at $30^{\circ} \mathrm{C}$.

\section{Results and Discussion}

The adaptation and survival abilities of halophilic microorganisms in a wide range of salinities $(0.5-25 \%)$ offer potential applications in various fields of biotechnology [23]. The osmophilic feature of honey suggests that it is being a good media for the presence of halophilic spore forming bacteria. Among these, the honey isolate Bacillus subtilis NRC$B 233 b$ was identified on the basis of morphological examination, 16S rRNA sequence and biochemical tests (API). The cells were rod shaped, Gram positive, motile and spore forming. Colonies were circular and cream, no pigment formed. The isolate grew optimally at $50^{\circ} \mathrm{C}$ and $\mathrm{pH} 5$. At $60^{\circ} \mathrm{C}$ the growth was noticeably decreased. The culture grew well when the medium was supplemented with different concentrations of $(\mathrm{NaCl} 0-12 \%)$ but it did not grow at higher $\mathrm{NaCl}$ concentration $(15 \% \mathrm{NaCl})$ and the maximum growth was observed at $4 \% \mathrm{NaCl}$. The $16 \mathrm{~S}$ rRNA gene sequence analysis indicated that the isolate was Bacillus sp. with $98 \%$ identity to any of these three species Bacillus spp., or B. licheniformis, or $B$. subtilis and they clustered into a monophyletic line in a phylogenetic tree. To identify the isolate to a definite species the analogical electrophoresis, using NEB cutter was applied to identify the $16 \mathrm{~S}$ rRNA results, which have been sequenced. The isolate showed different $A l u \mathrm{I}$ fragments which differ to the $A l u \mathrm{I}$ fragments generated from 16S rRNA sequence of $B$. subtilis, or B. licheniformis or B. amyloliquefaciens. The API results confirmed that the isolate is belonging to Bacillus subtilis.

The isolate was selected for further studies since it appeared to be the best producer of extracellular dextranase. The preliminary experiment using dextran as substrate revealed that Bacillus subtilis NRC-B233b exhibited high dextranase production $(258 \mathrm{U} / \mathrm{ml})$ in liquid culture. The chromatography of the compounds produced by incubating dextran $(250 \mathrm{kD})$ with the crude enzyme suggested a random endo-type hydrolysis resulting in liberation of long-chain oligomers together with glucose and isomaltose units. Solid state fermentation (SSF) holds tremendous potential for the production of enzymes. It has special interest in those processes where the crude fermented products could be used directly as enzyme sources [11]. Accordingly, different types of cheap starch rich materials were applied under SSF conditions. The results in Fig. 1 showed that dextranase was produced using corn flour, wheat flour, wheat bran, commercial starch and grinded rice as substrates. The highest enzyme activity $(61.3 \mathrm{U} / \mathrm{g})$ was achieved by using corn flour. Starch is known to be a slow release carbon source and a better substrate for enzyme production compared to simple sugars that lead to catabolite repression [24]. On contrary, Abdel-Naby et al., [25] reported that the use of starch led to drastic decrease in enzyme production. The previous results indicated that the major regulatory mechanism of dextranase is constitutive. The mutant Lipomyces starkeyi produced constitutive dextranase when grown on glucose, fructose and sucrose as well as on dextran [26]. A unique character of this isolate was its ability to grow and produce dextranase in the absence and presence of $\mathrm{NaCl}(0-15 \mathrm{~g} / \mathrm{l})$ without reduction in enzyme production (data not shown). It could be concluded that the halophilic character of the osmphilic honey isolate not obligatory led to increase or decrease in enzyme production. On contrary, Halobacillus sp. MA-2 which was previously isolated from saline soil exhibited maximum amylase activity in the medium containing $5 \%(\mathrm{w} / \mathrm{v}) \mathrm{NaCl}$ [3] 


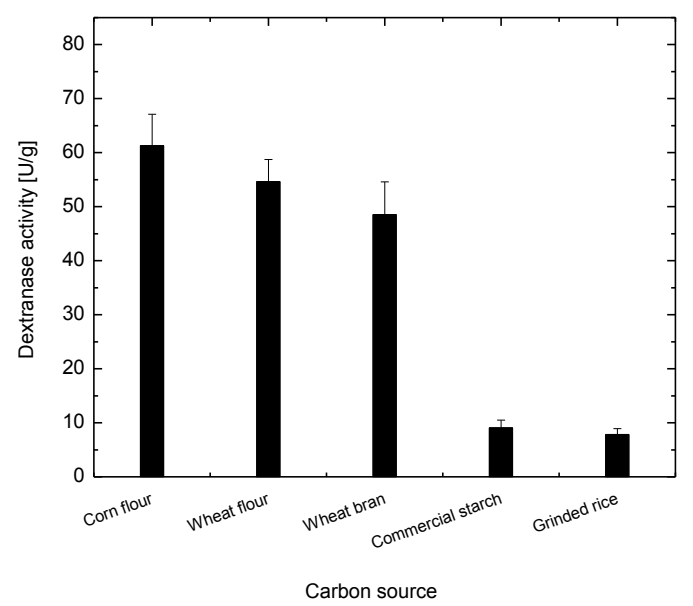

Figure 1. Effect of different starchy raw materials on dextranase production from Bacillus subtilis NRC-B233b.

The optimum temperature for maximum enzyme production was obtained at $37^{\circ} \mathrm{C}(108.2$ $\mathrm{U} / \mathrm{ml}$ ). Below and above this temperature there was a clear decrease in enzyme production (Fig 2). The enzyme activity was increased by increasing the time of incubation to reach the maximum value $(158.9 \mathrm{U} / \mathrm{g})$ after $32 \mathrm{hrs}$. There was a gradual decrease in the activity by increasing incubation periods from (48 to $72 \mathrm{hrs}$ ) (data not shown). Study of different moisture content of culture on dextranase production by Bacillus subtilis NRC-B233b was also investigated. As shown in figure 3, the maximal enzyme production of about $170.6 \mathrm{U} / \mathrm{g}$ was achieved in culture of $20(\mathrm{v} / \mathrm{w})$. The strain showed dextranase production in a broad $\mathrm{pH}$ range from 3 to 11. An increase in enzyme production was observed by increasing the alkalinity of the medium and the maximum enzyme production $(216.1 \mathrm{U} / \mathrm{g})$ was obtained at pH 10 (Fig 4). Similar results were reported by Yamaguchi and Gocho [27] who showed that Brevibacterium dextranase had an optimum dextranase activity at $\mathrm{pH} 8.0$ and $37^{\circ} \mathrm{C}$. On contrary, Bhatia et al., [28] 2010 reported that the maximal Paecilomyces lilacinus dextranase production was achieved at $\mathrm{pH} 6.0$ and $30^{\circ} \mathrm{C}$. The influence of different salts concentrations on dextranase production is shown in fig 5 . The results showed that $(0.1 \mathrm{M})$ of different salts have variable effects on dextranase production. The enzyme production increased in the presence of $\mathrm{KCl}$ and $\mathrm{AlCl}_{3}$ and the maximum enzyme activity was noticed in the presence of $\mathrm{CrCl}_{3}(447.58 \mathrm{U} / \mathrm{g})$. The influence of different concentrations of $\mathrm{CrCl}_{3}$ $(0.025-2 \mathrm{M})$ on the enzyme activity showed that a gradual increase in enzyme activity was obtained by increasing the concentration of $\mathrm{CrCl}_{3}$ from 0 up to $0.175 \mathrm{M}$. Further increase in salt concentration resulted in a slight decrease in enzyme activity (Fig. 6). This result could be explained that $\mathrm{CrCl}_{3}$ might act as dextranase stimulator. Different organic nitrogen sources were separately added in a concentration of $5 \mathrm{~g} / \mathrm{L}$ to the fermentation media to evaluate their effects on dextranase activity. The results in fig. 7 clearly revealed that, casein, ammonium chloride, yeast extract and corn steep increased the activity. The maximum activity of $1076.8 \mathrm{U} / \mathrm{g}$ was obtained in peptone culture. On the other hand, urea and beef extract had adverse effect on dextranase activity. The different concentrations of peptone $(1-8 \mathrm{~g} / \mathrm{L})$ were added to culture medium to investigate the effect of this important nutrient on enzyme production. The results showed that peptone added in concentration of $20 \mathrm{~g} / 1$ was the best for dextranse production (data not shown). However, polypeptone was 
found to be the most effective nitrogen source for Brevibacterium dextranase production as reported by other authors [27]. Non-ionizing radiation, such as ultraviolet (UV) light, exerts its mutagenic effect by exciting electrons in molecules. The goal of this experiment was to improve the activity of the enzyme by using UV mutated variant of Bacillus subtilis NRC$B 233 b$. The isolate was exposed to different doses of ultraviolet irradiation. The data in Fig 8 showed that enzyme activity was increased by the time of exposure to UV lamp. Maximum dextranase activity $2842.3 \mathrm{U} / \mathrm{g}$ was obtained by using mutant cells exposed to UV for $15 \mathrm{~min}$. Further exposure of culture to UV lamp decreased the dextranase activity gradually. The stability of mutagenic Bacillus subtilis $N R C-B 233 b$ for dextranase production was tested. The results referred to great stability of the mutagenic isolate by using repeated batch technique for 10 times without reduction in its activity. Hild et al., [29] reported in Paenibacillus sp. dextranase mutant pool with improved thermostability and activity. The use of ultrafilteration for downstream processing would result in one-step, cost-effective method of recovery for dextranase. Ultrafilteration of the culture broth using membrane PLGC cassett of $10 \mathrm{kD}$ resulted in $84.2 \%$ dextranase recovery. The result indicated that dextranase aggregated on low molecular weight cutoff membranes. The concomitant recovery of dextranase using $70 \%$ acetone showed recovery of about $37.3 \%$ and 112.2 fold purifications (Table. 1.).

Table1. Partial purification steps of Bacillus subtilis NRC-B233b dextranase.

\begin{tabular}{|c|c|c|c|c|c|c|}
\hline $\begin{array}{c}\text { Purification } \\
\text { steps }\end{array}$ & $\begin{array}{c}\text { Total } \\
\text { activity } \\
(\mathrm{U})\end{array}$ & $\begin{array}{c}\text { Recovered } \\
\text { activity } \\
(\%)\end{array}$ & $\begin{array}{c}\text { Total } \\
\text { protein } \\
(\mathrm{mg})\end{array}$ & $\begin{array}{c}\text { Recovered } \\
\text { protein } \\
(\%)\end{array}$ & $\begin{array}{c}\text { Specific } \\
\text { activity } \\
(\mathrm{U} / \mathrm{mg})\end{array}$ & $\begin{array}{c}\text { Purification } \\
\text { fold }\end{array}$ \\
\hline Culture filtrate & 249931 & 100.0 & 4477.4 & 100.0 & 55.8 & 1 \\
\hline \begin{tabular}{c} 
Ultra filtration \\
\hline $\begin{array}{c}\text { Acetone } \\
(70 \%)\end{array}$
\end{tabular} & 201446 & 84.2 & 1276.5 & 28.5 & 164.9 & 2.96 \\
\hline
\end{tabular}

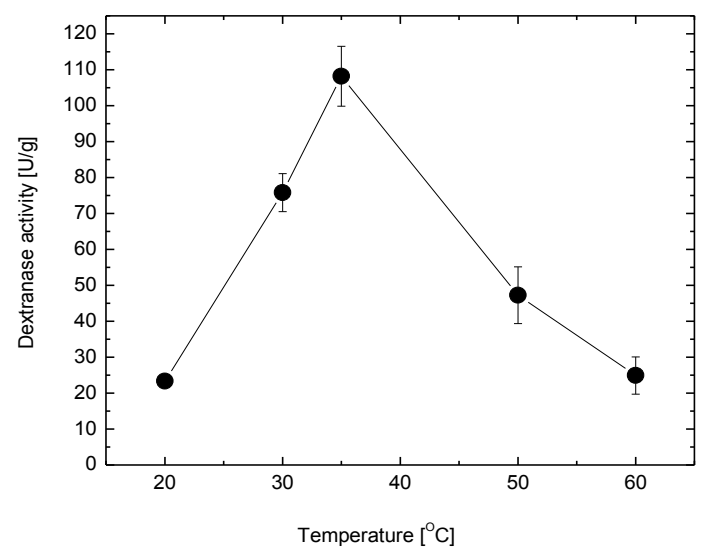

Figure 2. Effect of different temperature on dextranse production from Bacillus subtilis $N R C-B 233 b$. 


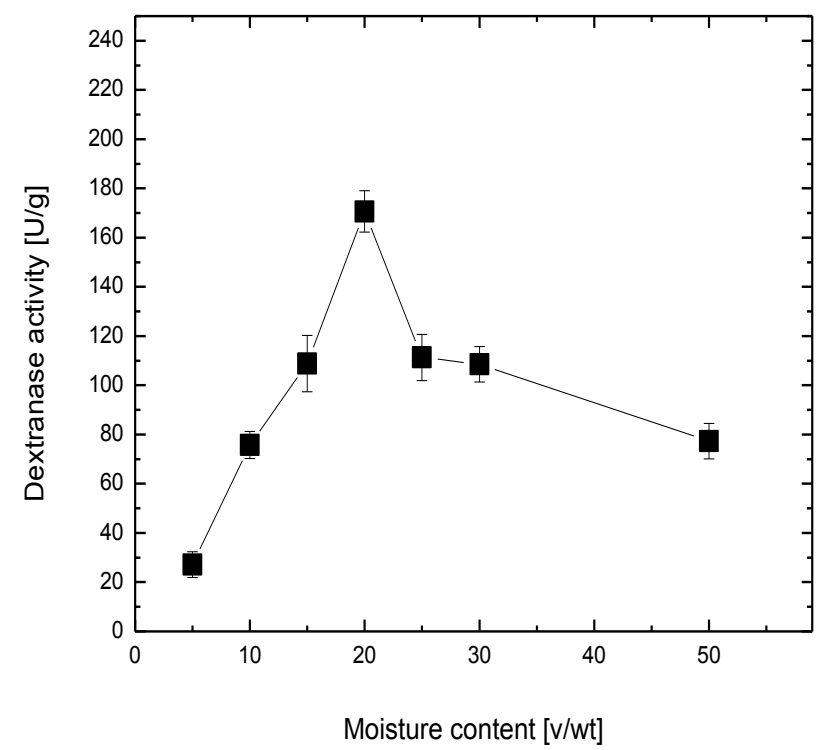

Figure 3. Effect of different moisture content on dextranse production from Bacillus subtilis $N R C-B 233 b$.

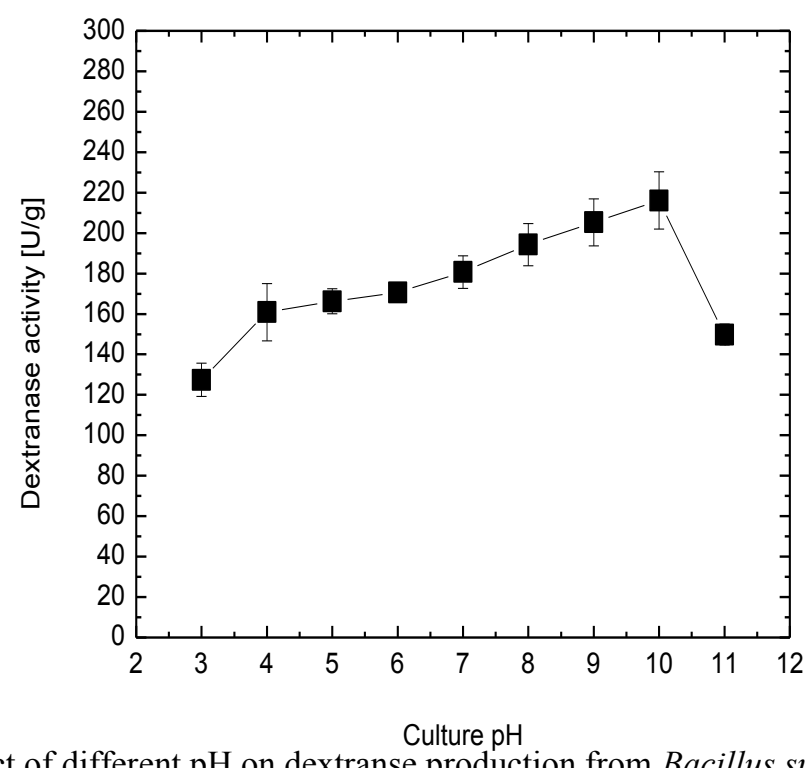

Figure 4. Effect of different $\mathrm{pH}$ on dextranse production from Bacillus subtilis NRC-B233b.

The properties of the partially purified enzyme in Figs $(9,10)$ clearly appeared that high temperature and alkaline media were the most favorable for the enzyme activity. The enzyme showed optimal activity at $70^{\circ} \mathrm{C}$, indicating that an increase in activity with temperature offsets the thermal denaturation. It was reported that the optimal temperature for Thermotoga lettingae TMO dextranse was $55-60^{\circ} \mathrm{C}$ during 15 min incubation [31]. In our study, the optimum $\mathrm{pH}$ for dextranase activity was 9. On contrary, Wynter et al., [32] reported that dextranase of Thermoanaerobacter sp. exhibited its optimum $\mathrm{pH}$ between 5 
and 6. Study on the thermal stability of the partially purified dextranase showed that the enzyme was fairly stable to heat treatment in absence of the substrate (Table 2). At $75^{\circ} \mathrm{C}$ the enzyme retained its complete stability for one hour. On contrary, the alkaline dextranase from a Brevibacterium was stable at temperatures below $60^{\circ} \mathrm{C}$ [27]. An attractive industrial application of thermostable dextranase is sugar processing. Penicillium $\mathrm{sp}$. and Chaetomium gracile dextranases that are active and stable above $55^{\circ} \mathrm{C}$ would improve processing of dextran-contaminated cane juice in the sugar industry [33]. The partially purified dextranase exhibited a broad $\mathrm{pH}$ stability range (4-10), especially on the alkaline side (Table. 3 ). This is in agreement with the recently published work of Kim and Kim [31]. The broad pH stability of our enzyme could be useful in sugar processing, which involves both acidic and alkaline conditions.

Table 2.Thermal stability of Bacillus subtilis $N R C-B 233 b$ dextranase.

Relative values of dextranase activity of enzyme, expressed in \%, and obtained by Berridge's method.

\begin{tabular}{|c|c|c|c|c|}
\hline $\begin{array}{c}\text { Temperature } \\
\left({ }^{\circ} \mathbf{C}\right)\end{array}$ & \multicolumn{3}{|c|}{ Exposure time (min.) } \\
\hline & $\mathbf{3 0}$ & $\mathbf{6 0}$ & $\mathbf{9 0}$ & $\mathbf{1 2 0}$ \\
\hline $\mathbf{4 0}$ & $100 \pm 0.831$ & $100 \pm 1.029$ & $100 \pm 0.866$ & $100 \pm 1.092$ \\
\hline $\mathbf{4 5}$ & $100 \pm 1.016$ & $100 \pm 0.917$ & $100 \pm 1.029$ & $100 \pm 2.008$ \\
\hline $\mathbf{5 0}$ & $100 \pm 2.003$ & $100 \pm 0.734$ & $100 \pm 2.033$ & $100 \pm 1.049$ \\
\hline $\mathbf{5 5}$ & $100 \pm 1.022$ & $100 \pm 1.021$ & $100 \pm 1.050$ & $100 \pm 0.953$ \\
\hline $\mathbf{7 5}$ & $100 \pm 0.909$ & $100 \pm 1.034$ & $80.6 \pm 0.930$ & $80.6 \pm 2.057$ \\
\hline $\mathbf{6 5}$ & $100 \pm 0.746$ & $100 \pm 0.880$ & $100 \pm 2.090$ & $100 \pm 1.027$ \\
\hline & $100 \pm 0.820$ & $100 \pm 2.019$ & $100 \pm 1.070$ & $100 \pm 1.030$ \\
\hline & & $100 \pm 0.905$ & $100 \pm 1.037$ & $100 \pm 1.025$ \\
\hline & & & & \\
\hline
\end{tabular}




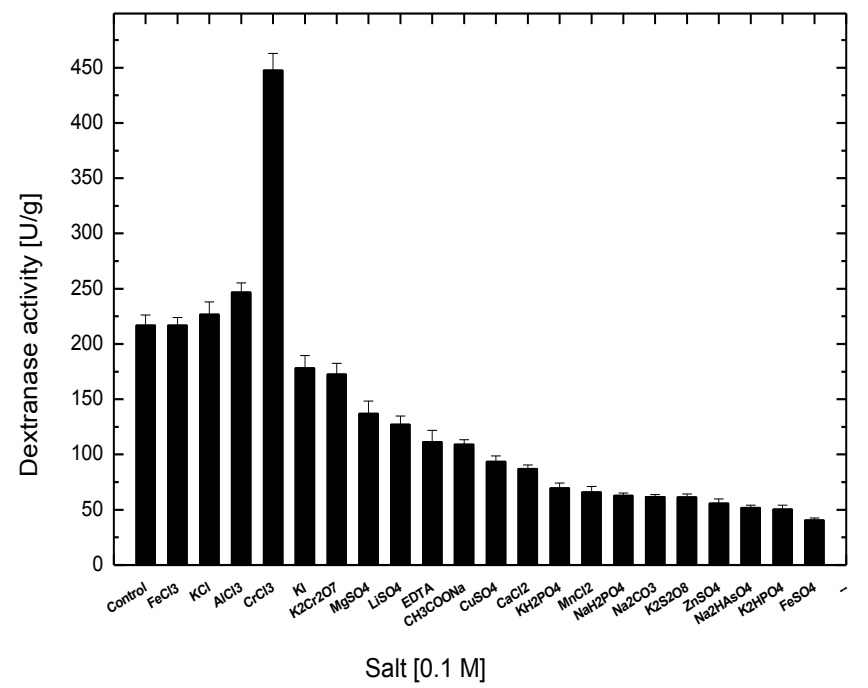

Figure 5. Effect of different salts on dextranase production from Bacillus subtilis NRC$B 233 b$.

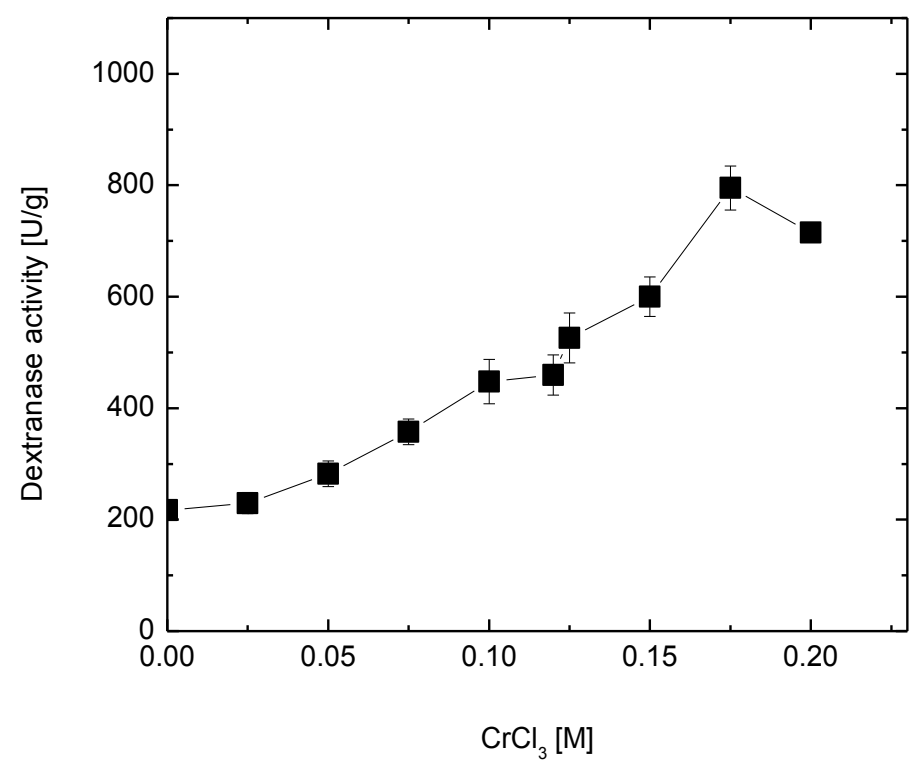

Figure 6. Effect of different concentrations of Chromium chloride on dextranase production from Bacillus subtilis NRC-B233b.

The partially purified dextranase was greatly affected by the metal ions addition, the halophilic feature of this enzyme appeared clearly when the enzyme activity increased about 4 fold in the presence of $1.92 \mathrm{M} \mathrm{NaCl}$ (Fig.11). The halophilic bacteria's enzymes are thus active at salt concentrations which inhibit or even denature many enzymes of non-halophilic organisms. This must be reflected in marked differences in the composition and properties of 


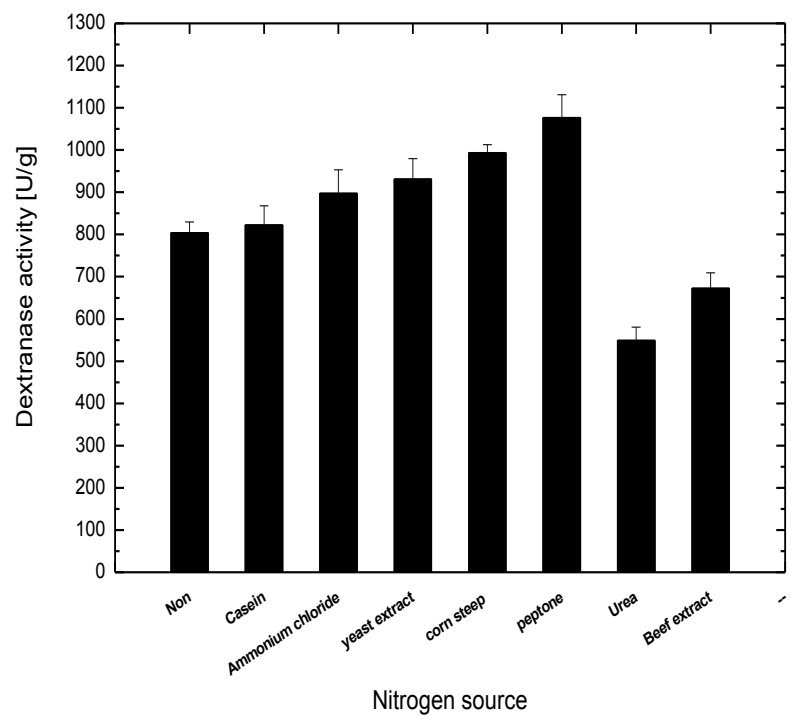

Figure 7. Effect of different nitrogen sources on dextranse production from Bacillus subtilis $N R C-B 233 b$.

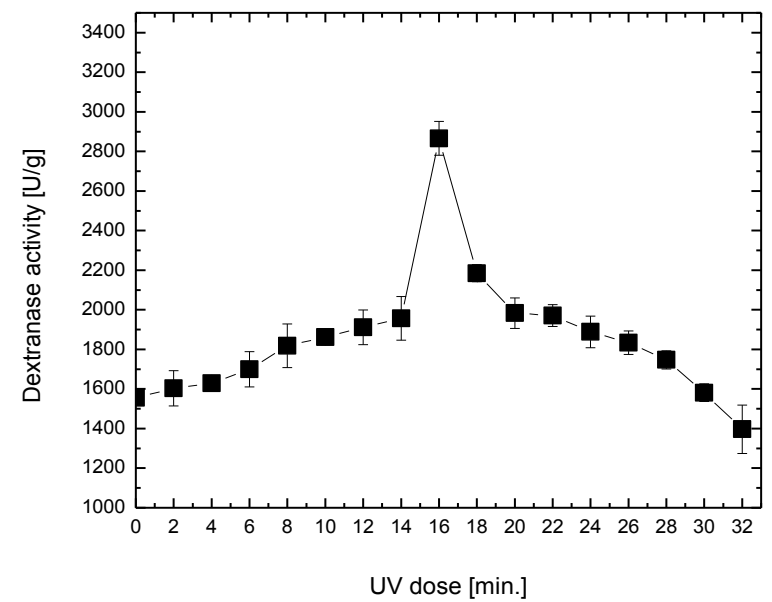

Figure 8. Effect of UV irradiation (min.) on the activity of dextranase.

the protein molecules [30]. It was suggested that the halophilic enzymes has smaller molecular weight than most other enzymes, which would make them more resistant to being salted out. However, no halophilic dextranase have yet been studied in sufficient detail to give substantial support to this hypothesis. The effect of different salts showed that EDTA, $\mathrm{CaCl}_{2}, \mathrm{KCl}, \mathrm{Mg}_{2} \mathrm{SO}_{4}$ and $\mathrm{CrCl}_{3}$ all enhanced enzyme activity and the relatives activities (\%) were $264.4 \pm 0.053,228.8 \pm 0.22,207.6 \pm 0.015,, 181.25 \pm 0.029$ and $125 \pm 0.031$ respectively (data not shown). Whereas dextranase activity was strongly inhibited by $\mathrm{MnCl}_{2}$ and $\mathrm{AlCl}_{3}$, and the retained activities were $31.3 \pm 0.001,36.9 \pm 0.001$, respectively. On the other hand 
$\mathrm{CuSO}_{4}$ and $\mathrm{ZnSO}_{4}$ reported 77.5 \pm 0.064 and 77.5 \pm 0.064 retained activity. Sugiura et al., [34] reported that dextranase from Penicillium funiculosum was activated by $\mathrm{Co}^{2+}, \mathrm{Mn}^{2+}$ and $\mathrm{Cu}^{2+}$, and inactivated by $\mathrm{Ag}^{+}, \mathrm{Hg}^{2+}, N$-bromosuccinimide and iodine. On contrary Thermotoga lettingae TMO dextranase activity was not significantly affected by the presence of metal ions, except for the strong inhibition by $1 \mathrm{~m} \mathrm{M} \mathrm{Fe}^{2+}$ and $\mathrm{Ag}^{2+}$ [31]. The substrate specificity of Bacillus subtilis $N R C-B 233 b$ partially purified dextranase on different types of carbohydrates and the rate of enzyme hydrolysis with various glycosidic linkages was done. This enzyme could act efficiently on high and low molecular weight dextran. Where it could preferentially split a series of dextrans and their derivatives (Sephadex), the rate of hydrolysis was dependent on the molecular weight of the substrate. The results presented in

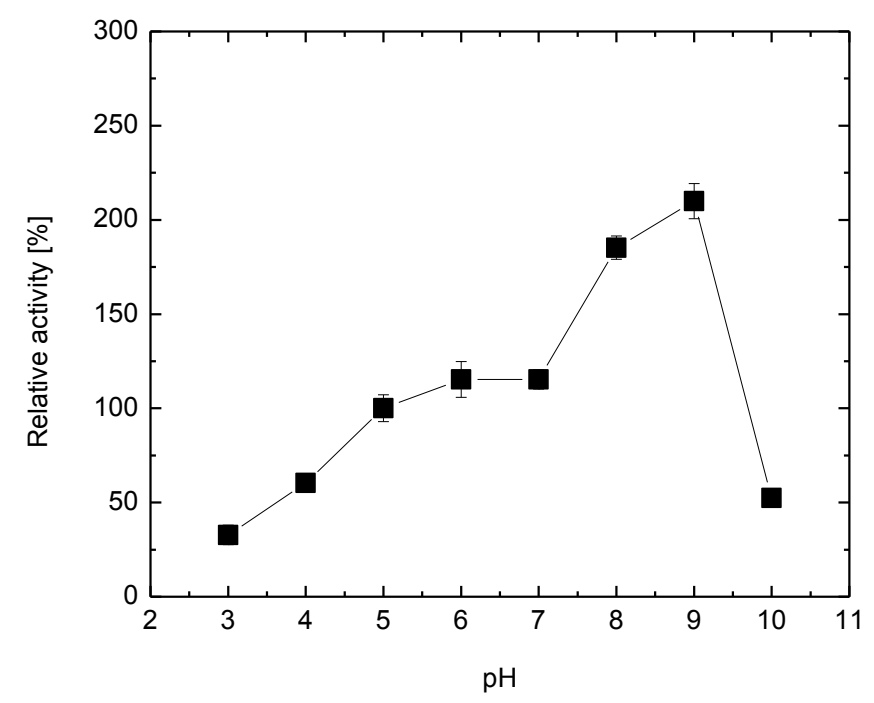

Figure 9. Effect of different $\mathrm{pH}$ on partial purified dextranse activity.

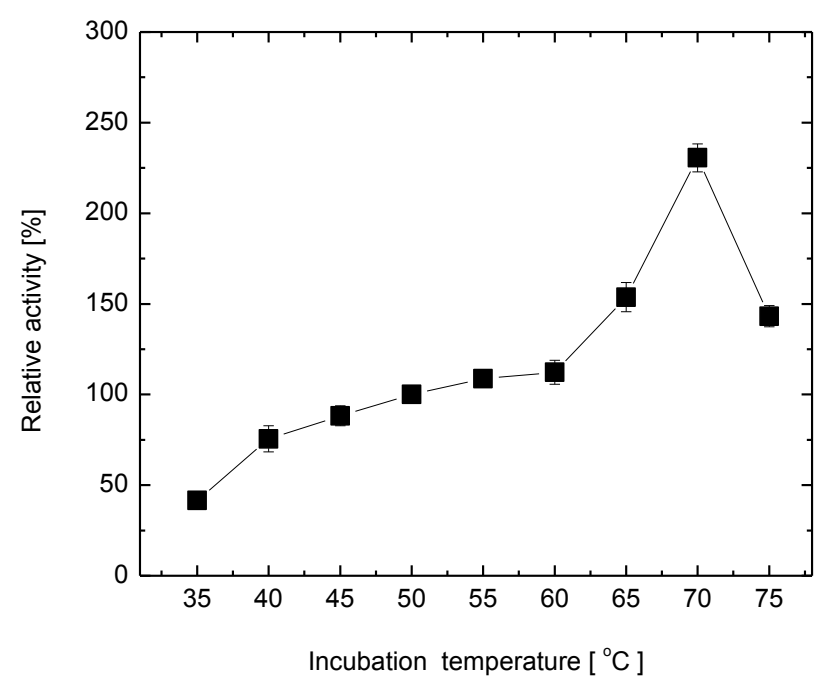

Figure 10. Effect of different temperatures on partial purified dextranse activity. 


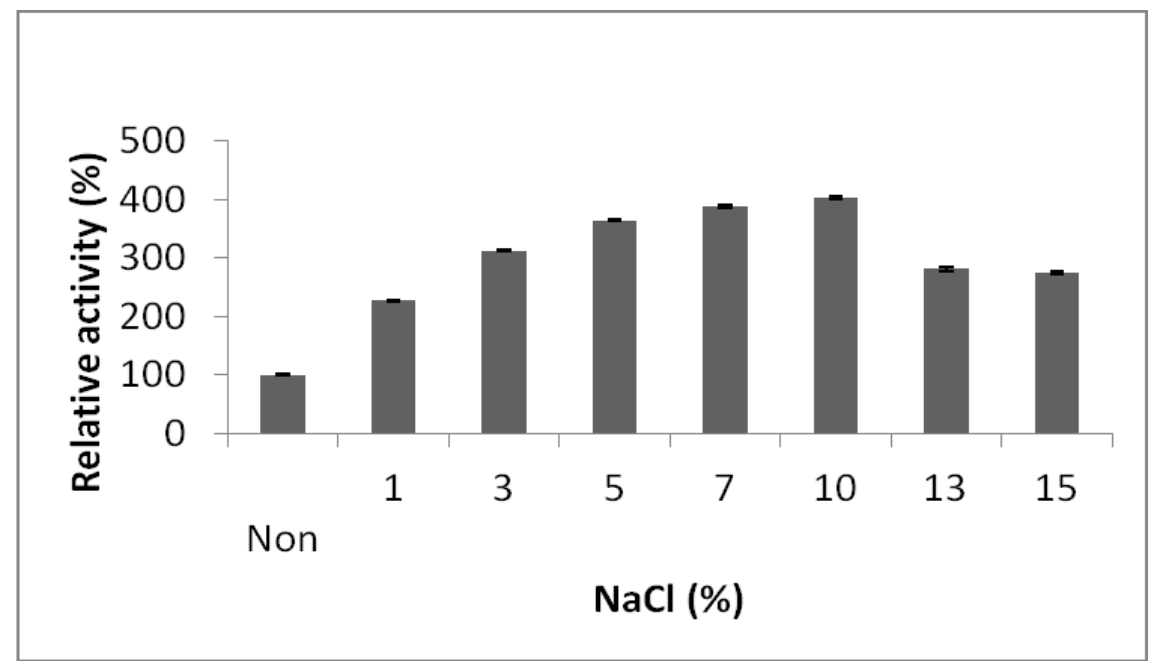

Figure 11. Effect of different $\mathrm{NaCl}$ concentrations on partial purified dextranse.

Table3. $\mathrm{pH}$ stability of the partially purified Bacillus subtilis NRC-B233b dextranase. Relative values of dextranase activity of enzyme, expressed in \%, and obtained by Berridge's method.

\begin{tabular}{|c|c|c|c|c|}
\hline \multirow{2}{*}{ pHs } & \multicolumn{4}{|c|}{ Exposure time (min.) } \\
\hline & $\mathbf{3 0}$ & $\mathbf{6 0}$ & $\mathbf{9 0}$ & $\mathbf{1 2 0}$ \\
\hline $\mathbf{5 . 0} *$ & $100 \pm 0.331$ & $100 \pm 0.844$ & $90 \pm 1 . .066$ & $83 \pm 0.992$ \\
\hline $\mathbf{6 . 0}$ & $100 \pm 0.0216$ & $100 \pm 0.217$ & $100 \pm 0.829$ & $100 \pm 0.708$ \\
\hline $\mathbf{7 . 0}$ & $100 \pm 0.303$ & $100 \pm 0.534$ & $100 \pm 0.933$ & $100 \pm 1.049$ \\
\hline $\mathbf{8 . 0}$ & $100 \pm 0.666$ & $100 \pm 1.021$ & $100 \pm 0.650$ & $100 \pm 0.553$ \\
\hline $\mathbf{9 . 0}$ & $100 \pm 0.546$ & $100 \pm 0.919$ & $100 \pm 0.66$ & $100 \pm 0.930$ \\
\hline $\mathbf{1 0 . 0}$ & $100 \pm 1.046$ & $95 \pm 0.180$ & $81 \pm 0.590$ & $80 \pm 0.627$ \\
\hline
\end{tabular}

Table 4. reported that blue dextran $(1 \mathrm{kD})$ gave the maximum relative activity $(273.8 \%)$. It was also reported that Penicillium notatum dextranase could act on different types of dextran and the rate of hydrolysis was independent of the molecular weight of substrate [35]. The digestion products from the Sephadex derivatives showed the presence of reducing sugars. The previous result suggests that dextranase is an interesting enzyme for removal of dental cariogenic plaque deposits [36]. A great dextranolytic activity was found when starch $(\alpha-1,4$ and $\alpha-1,6$ glycosidic linkages), amylopectin, inulin and sucrose ( $\alpha-1,2$ glycosidic linkages) were used as substrates. 
Table 4. Action of Bacillus subtilis NRC-B233b dextranase on various carbohydrates.

\begin{tabular}{|c|c|c|}
\hline Substrates & Main linkage & Relative activity (\%) \\
\hline *Dextran (250kD) & $\alpha-1,6$ & 100 \\
\hline Dextran (200-275 kD) & $\alpha-1,6$ & 79.2 \\
\hline Blue dextran (2 kD) & $\alpha-1,6$ & 273.8 \\
\hline Sephadex G-100 (1-10 kD) & $\alpha-1,6$ & 112 \\
\hline Starch & $\alpha-1,6$ & 228 \\
\hline Amylopectin & $\alpha-1,6$ & 165 \\
\hline Maltose & $\alpha-1,4$ & 71 \\
\hline Inulin & $\alpha-1,4$ & 170 \\
\hline Sucrose & $\alpha-1,2$ & 100 \\
\hline *Control. & & \\
\hline
\end{tabular}

Competition studies with different amounts of dextran and starch as substrates showed consistency with the hypothesis that hydrolysis of dextran and starch occurs at two independent active sites [37-39]. Degradation of alpha-linked D-gluco-oligosaccharides and dextrans by an isomalto-dextranase preparation from Arthrobacter globiformis T6 was also reported by other authors [39]. In laboratory study, the treatment of viscous sugar cane juice with different dextranase concentrations resulted in clear visual dextran hydrolysis. The results showed gradual decrease in viscosity 68\%, 72\%, 96\% respectively (Table. 5). Sugarcane juices have high levels of glucose, fructose, and particularly sucrose. Mannitol will also often be present when dextran is present in cane juice because both are formed mainly from Leuconostoc mesenteroides [40]. These short and long chain carbohydrate sugars could potentially affect the activity of dextranase if applied in sugar factories. None of the sugars tested showed any adverse effect on dextranase activity. This result confirms the capability of application of Bacillus subtilis NRC-B233b dextranase in sugar industries. Finally, the crude enzyme was highly tolerant to repeated freezing and thawing, the activity remaining at $100 \%$ for three months.

Table 5. The effect of different Bacillus subtilis NRC-B233b dextranase concentrations on sugar cane juice viscosity.

\begin{tabular}{|c|c|}
\hline Viscosity Reduction (\%) & Enzyme added (U) \\
\hline 68 & 237 \\
\hline 82 & 475 \\
\hline 96 & 712 \\
\hline 97 & 950 \\
\hline 97 & 1185 \\
\hline
\end{tabular}

\section{Conclusion}

In this study we focused on isolation of halophilic bacteria from honey as new source. The mutagenic honey isolate produced a novel halophilic constitutive dextranase characterized 
by unique features, like halophilic, thermostability and $\mathrm{pH}$ stability. Furthermore, cheap substrates like corn starch would be a superior alternative to the already available expensive dextran, since $30-40 \%$ of the production cost of industrial enzymes is accounted by the cost of the growth medium. The Bacillus subtilis $N R C-B 233 b$ dextranase showed wide substrate specificity, also it not affected by the presence of some sugars. The laboratory experiment highly proved that this enzyme could play role in sugar cane industry.

\section{References}

1. Ventosa A, Nieto J J and Oren A, Microbiol Mol Biol Rev., 1998, 62, 504-544.

2. Xue Y, Ventosa A, Wang X, Ren P, Zhou P, and Ma Y, Int J Syst Evol Microbiol., 2008, 58, 2828-283.

3. Amoozegar M A, Malekzadeh F, and Malik K A, J Microbiol Methods., 2003, 52, 353-359.

4. Hutcheon GW, Nishi V, and Albert B, Extremophiles., 2009, 9, 487-492.

5. Oren A, Frank L, Richardson PAL, and Laszlo N C, Extremophiles., 2005, 9, 275279.

6. Tokunaga H, M. Ishibashi T, Arakawa M, and Tokunaga M, FEBS letteres., 2004, 558, 7-12.

7. Sankpal N V, Joshi A P, Sainkar A P, Kulkarni, and B D, Process Biochem., 2001,37, 395-403.

8. Hayward A C and sly L I, J Appl Bact., 1976, 40, 355 - 364.

9. Clarke M, Sugary Azucar.1997.92, 38-46.

10. Pandey A, Process Biochem., 1992, 27, 109-117.

11. Pandey A, Wiley Eastern Publishers, New Delhi, 1994, 3-10.

12. Nigam P and Singh D, J Basic Microbial., 1994, 34,405-423.

13. López A C and Alippi. A M, Int J Food microbiol., 2007, 117, 175-184.

14. Rodriguez H, de las Rivas B, and Muňoz R, Int J Food Microbiol., 2007, 115, 70 78.

15. Shah M M, Lihara $\mathrm{H}$, Noda $\mathrm{M}$, Song $\mathrm{S} \mathrm{X}, \mathrm{P}$ H. Nhung, $\mathrm{K} \mathrm{K}$ and Ghkusu $\mathrm{Y}$, Int J Syst Evol Microbiol., 2007, 57 25-30.

16. Balch W E, Fox G E, Magrum R J, Wolfe R S, Microbiol Rev., 1979, 43,260-296.

17. Somogy M ., 1952, J Biol Chem., 1952, 195, 19-23

18. Lowery OH, Rosenbrough N J, Farr A L, and Ranadall R J, J. Biol. Chem., 1956, 193, 265-276.

19. Block R J, Durrum E L, and Zweig G, New York, NY: Academic Press, New York, (1995) pp. 127.

20. Abdel-Fattah A F, Mahmoud D A R and Esawy M A Curr Microbiol., 2005, 51,402407.

21. Abdel-Aziz M S, Talkhan FN, and Janson J , J Appl. Sci Res., 2007, 3, 1509-1516.

22. Fukomoto J, The culture conditions of Rhizopus delemar and its lipase production. Kagaku to Kogyo (Osaka). 1963, 40, 80 - 89.

23. Margesin R, Schinner F. Appl. Environ. Microbiol. 2001, 67, 3127-3133.

24. Puri S, Beg Q K, Gupta R Curr. Microbiol.,2002, 44, 286-90.

25. Abdel-Naby M A, Ismail A M S, Abdel-Fattah A M, and Abdel-Fattah A F, Process. Biochem., 1999, 34, 391-398.

26. D. Kim, and D. F. Day, Lett Appl Microbiol., 1995, 20, 268-270.

27. T. Yamsguchi, S. Gocho, Agr Biol Chem. 1973, 37, 2527-2533.

28. S. Bhatia G, Bhakri M, Arora S K, Uppal, Batta S K, Sugar Tech. 2010, 12,133138. 
29. Hild E, Brumbley S M, Shea M G O, Nevalainen H, Bergquist P L A., Appl. Microbiol. Biotechnol. 2007, 75, 1071-1078.

30. Norberg P and. B V Hofsten., J Gen Microbiol., 1969, 55, 251-256.

31. Kim Y M, and Kim D, Appl Microbiol Biotechnol., 2010, 85, 581-58.

32. Wynter C, Patel' Peter Bain B K C, de Jersey J, Hamilton S, Inkerman P A., FEMS Microbiol Lett., 2006, 140, 271-276.

33. Halikova E, Susi P, and Korpela T, Microbiol. Mol. Biol. Reviews., 2005, 69, 306325.

34. Sugiura' A, Akira A, Ogiso T, Kato K, and Asano H. Biochim Biophys Acta., BBAEnzymology., 1973, 309, 357-362.

35. Pleszczyńsk M, Rogalsk J I, Szczodrak J, and Fiedurek. J Mycol Res., 1996, 100, 681-686.

36. Lifschitz B G, Bauer S, J Dent Res 1976, 55, 886-892.

37. Kim D W, Heo S J, and Ryu S J, WO patent publication 2001, 01/66570.

38. Lee S Y, Lee J H, Robyt J F., Seo E S., Park H J, and Kim D, J Microbiol Biotechnol. 2003, 13, 313-316.

39. Ryu S J, Kim D, Ryu H J, Chiba S, Kimura A, Day D F, Biosci Biotechnol Biochem., 2000, 64, 223-228.

40. Eggleston G, Food Chem. 2002, 78, 99-107. 


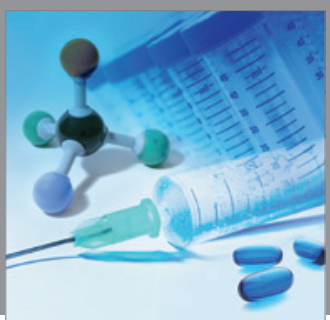

International Journal of

Medicinal Chemistry

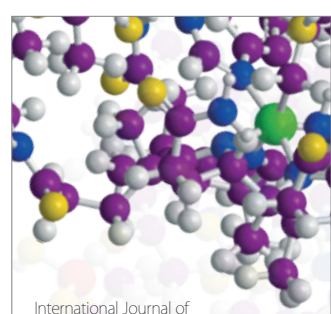

Carbohydrate Chemistry

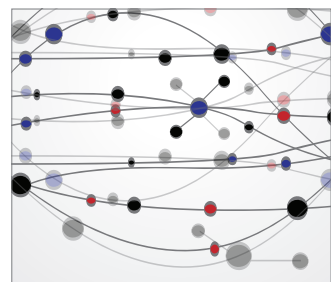

The Scientific World Journal
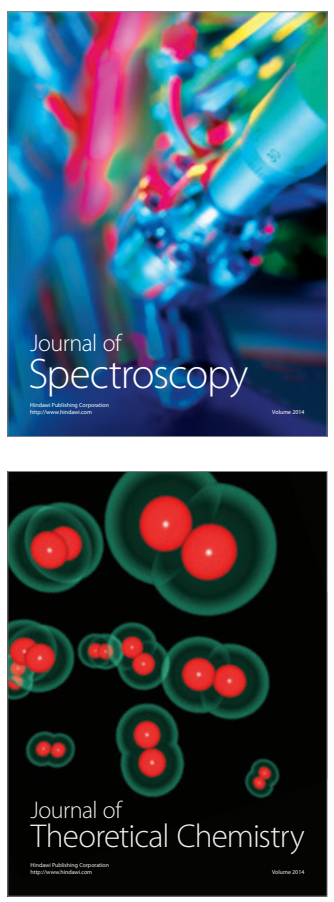
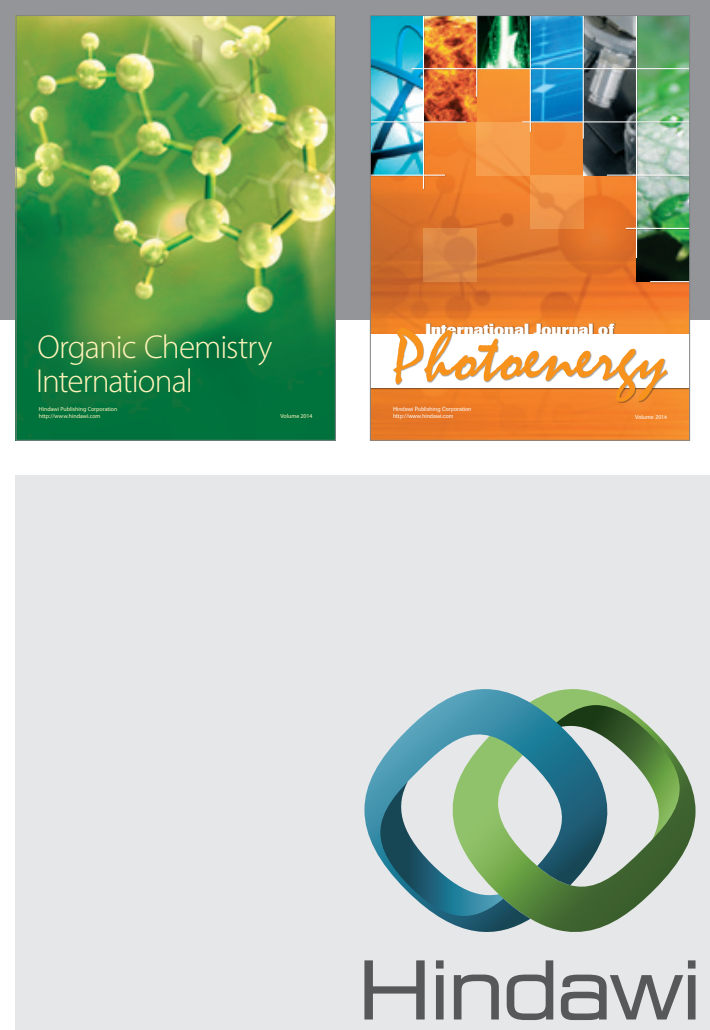

Submit your manuscripts at

http://www.hindawi.com
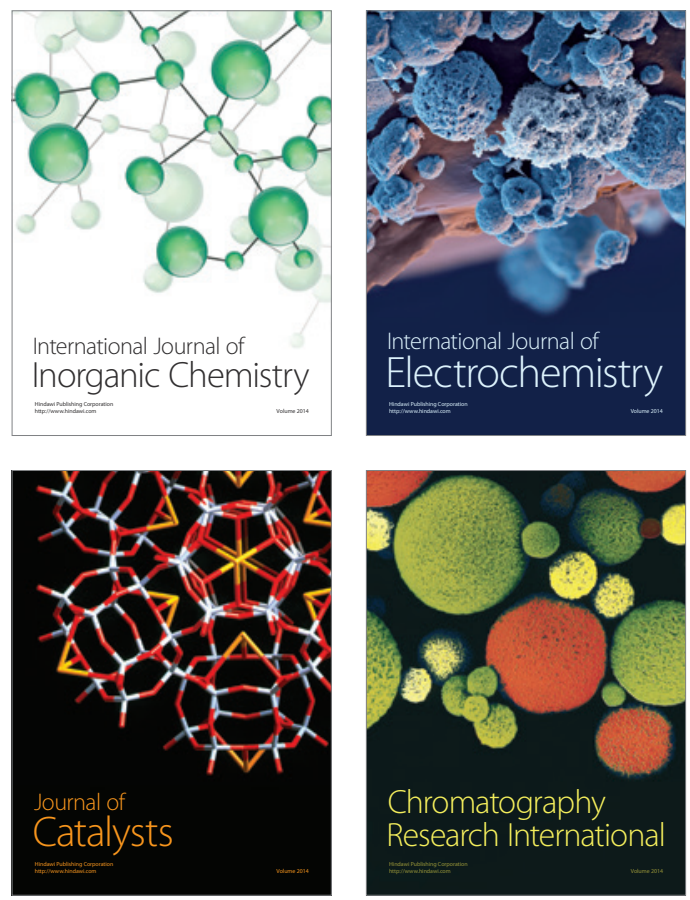
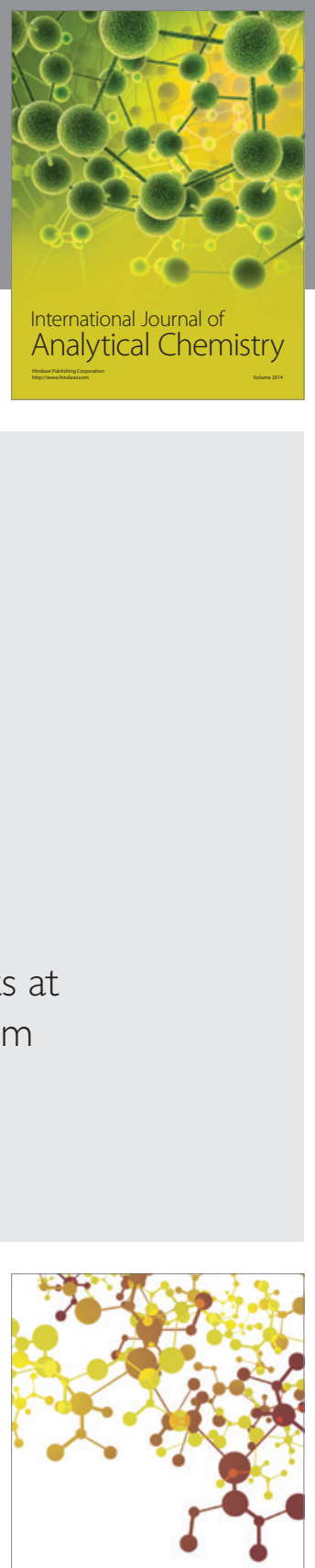

Journal of

Applied Chemistry
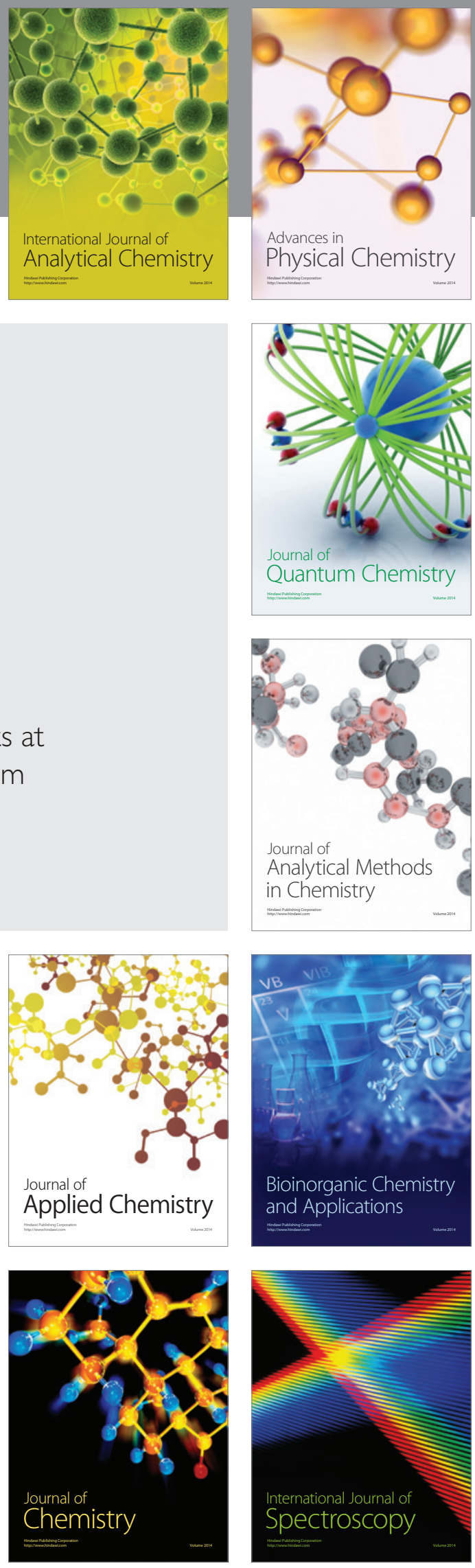